Info Artikel Diterima Januari 2018

Disetujui Maret 2018

Dipulikasikan April 2018

\title{
ANALISIS PEMASARAN KERIPIK TEMPE DI DESA LEREP KECAMATAN UNGARAN BARAT KABUPATEN SEMARANG
}

\author{
Arinda Afif Pratiwi, Dewi Hastuti, Istanto \\ Program Studi Agribisnis Fakultas Pertanian \\ Universitas Wahid Hasyim Semarang \\ e-mail: arindaafif.pratiwi@gmail.com
}

\begin{abstract}
The purpose of this study are to determine the number of marketing channels, the amount of marketing margins and marketing efficiency of tempe chips in Lerep Village, West Ungaran District Regency. The basic method of research used is descriptive method of analysis. Determination of the sample area is done purposively in Lerep Village, West Ungaran District Regency. The number of respondents as many as 15 respondents. Data analysis cost analysis and marketing margin of each marketing channel, analysis of marketing efficiency of tempe chips each channel. The results showed that there are three channels of marketing tempe chips. Channel I consists of: Producer - Final Consumer, Channel II consists of: Manufacturer - Retailer - Final Consumer and Channel III consists of : Manufacturer - Wholesaler - Retailer - Final Consumer. Total marketing margin value on channel I is Rp. 4,380, channel II is Rp. 4,500, - and channel III is Rp. 4,500. The cost incurred on channel I is Rp. 120, on channel II of Rp. 513 and on channel III is Rp. 815. The marketing of tempe chips has shown an efficient value. It can be seen from marketing efficiency value of each channel is channel I equal to $0,26 \%$, channel II equal to $1,18 \%$, and channel III equal to $1,87 \%$. Channel II is an efficient channel in the marketing of tempe chips everyday.
\end{abstract}

Keywords: Tempe Chips, Marketing Channels, Marketing Margin, Marketing Efficiency

\section{PENDAHULUAN}

Agroindustri adalah kegiatan industri berupa pengolahan hasil pertanian yang melibatkan faktor penyedia alat dan jasa dalam proses kegiatannya untuk menghasilkan produk pertanian yang memiliki nilai tambah dan nilai jual lebih tinggi. Industri kecil menengah yang banyak dan berkembang di Kabupaten Semarang adalah industri makanan dan salah satunya keripik. Industri kecil di Kabupaten Semarang perlu ditingkatkan serta dikembangkan karena menyumbang terhadap pertumbuhan ekonomi daerah Kabupaten Semarang serta meningkatkan kesejahteraan masyarakat sekitar. Kecamatan Ungaran Barat menjadi sentra pembuatan keripik tempe yang tepatnya berada di Desa Lerep. 
Keripik tempe adalah salah satu olahan hasil pertanian yang memiliki nilai tambah yang cukup tinggi. Keripik tempe adalah jenis makanan ringan hasil olahan tempe yang sudah melalui beberapa proses pengolahan. Kadar protein keripik tempe cukup tinggi yaitu berkisar antara 23\% hingga 25\%. Tempe yang digunakan untuk pembuatan keripik tempe melalui proses yang sedikit berbeda dengan proses pembuatan tempe untuk sayur (Sarwono, 2007).

Pemasaran merupakan salah satu dari kegiatan yang pokok yang harus dilakukan oleh para pengusaha termasuk pengusaha tani (agribusinessman) dalam usahanya untuk mempertahankan kelangsungan hidupnya (survival), untuk mendapatkan laba, dan untuk berkembang. Berhasil tidaknya usaha tersebut sangat tergantung pada keahliannya di bidang pemasaran, produksi, keuangan dan sumber daya manusia (Firdaus, 2009).

Penelitian ini bertujuan untuk mengetahui banyaknya saluran pemasaran keripik tempe, besarnya margin pemasaran keripik tempe, dan efisiensi pemasaran keripik tempe di Desa Lerep Kecamatan Ungaran Barat Kabupaten Semarang.

\section{METODE PENELITIAN}

Metode yang digunakan dalam penelitian ini adalah metode diskriptif analisis, yaitu metode yang digunakan untuk meneliti status kelompok manusia, objek, kondisi, pola pemikiran kelompok peristiwa pada masa sekarang atau gambaran secara sistematis, aktual dan akurat mengenai fakta-fakta, sifat hubungan antar fenomena yang diselidiki (Nazir, 2005). Lokasi penelitian dilakukan di Desa Lerep Kecamatan Ungaran Barat Kabupaten Semarang yang merupakan sentra industri pembuatan keripik tempe. Metode pengambilan sampel responden menggunakan metode purposive sampling. Produsen yang dijadikan responden adalah produsen yang memiliki usaha pembuatan keripik tempe, masih berproduksi sampai dengan penelitian ini dilakukan. Responden yang diambil dalam penelitian ini adalah produsen yang kontinuitas produksinya sama sebanyak 15 produsen.

Adapun untuk penentuan sampel responden pedagang dan konsumen akhir dilakukan dengan teknik snowball (bola salju). Responden pedagang pengumpul dalam penelitian ini sebanyak 2 orang pengumpul/ pengepul. Sedangkan responden pengecer dalam penelitian ini sebanyak 7 orang dan jumlah konsumen akhir yang terdapat dalam penelitian ini sebanyak 7 orang. Data yang digunakan dalam penelitian ini adalah data primer dan data sekunder.

\section{Analisis Data}

\section{a. Analisis Saluran Pemasaran}

Saluran pemasaran keripik tempe dapat dianalisis menggunakan metode diskriptif analisis, yaitu metode yang digunakan untuk meneliti status kelompok manusia, objek, kondisi, pola pemikiran kelompok peristiwa pada masa sekarang atau gambaran secara sistematis, aktual dan akurat mengenai fakta-fakta, sifat hubungan antar fenomena yang diselidiki. Diskriptif analisis ini dijelaskan dalam sebuah informasi (Nazir, 2005). 
b. Margin pemasaran

Margin pemasaran keripik tempe ini dapat dihitung menggunakan rumus:

$\mathrm{VM}=(\mathrm{Pr}-\mathrm{Pf}) \times \mathrm{Q}$

Keterangan:

$\mathrm{VM}=$ Nilai Margin pemasaran $(\mathrm{Rp} / \mathrm{kg})$

$\operatorname{Pr}=$ Harga ditingkat konsumen $(\mathrm{Rp} / \mathrm{kg})$

Pf $=$ Harga ditingkat produsen $(\mathrm{Rp} / \mathrm{kg})$

Q = Jumlah yang Ditransaksikan (unit) (Sudiyono, 2002)

\section{c. Efisiensi Pemasaran}

$$
\mathrm{EP}=\frac{\mathrm{BP}}{\mathrm{HE}} \times 100 \%
$$

Keterangan:

$\mathrm{EP}=$ Efesiensi Pemasaran

$\mathrm{Bp}=$ Biaya Pemasaran

HE = Harga Eceran (Soekartawi, 2002)

Menurut Januwiata (2013), pemasaran dikatakan efisien apabila memenuhi kriteria sebagai berikut :

a. EP $<5 \%$ adalah efisien

b. EP $>5 \%$ adalah tidak efisien.

\section{HASIL DAN PEMBAHASAN}

Lerep adalah salah satu desa yang ada di wilayah Kecamatan Ungaran Barat Kabupaten Semarang Provinsi Jawa Tengah. Letaknya yang berada di tengah tengah wilayah Ungaran Barat menjadikan Desa Lerep sebagai pusat wilayah. Desa Lerep memiliki luas wilayah $\pm 6,82 \mathrm{~km}^{2}$ dengan kepadatan penduduk 1.311 jiwa $/ \mathrm{km}^{2}$. Desa Lerep merupakan desa yang terletak dekat dengan pusat kota Ungaran. Di Desa Lerep terdapat banyak usaha yang berkembang, salah satunya adalah usaha pembuatan keripik tempe, tumpi, keripik singkong, dsb. Karena usaha yang berkembang ini, Desa Lerep disebut sebagai "Keripik Center".

\section{Karakteristik Responden}

\section{Struktur Umur}

Tabel 1. Karakteristik Umur Responden

\begin{tabular}{ccccccccc}
\hline \hline \multirow{2}{*}{ Umur } & \multicolumn{2}{c}{ Produsen } & \multicolumn{2}{c}{ Pengepul } & \multicolumn{2}{c}{ Pengecer } & \multicolumn{2}{c}{ Konsumen } \\
& \multicolumn{2}{c}{ Akhir } \\
\cline { 2 - 9 } & Jml & $\%$ & Jml & $\%$ & Jml & $\%$ & jml & $\%$ \\
\hline $21-30$ & - & - & - & - & - & - & 2 & 28,57 \\
$31-40$ & 4 & 26,67 & 2 & $100 \%$ & 1 & 14,29 & 3 & 42,86 \\
$41-50$ & 5 & 33,33 & - & - & 2 & 28,57 & 2 & 28,57 \\
$51-60$ & 6 & 40 & - & - & 4 & 57,14 & - & - \\
\hline \hline Jumlah & 15 & 100 & 2 & 100 & 7 & 100 & 7 & 100 \\
\hline \hline
\end{tabular}

Sumber : Analisis Data Primer, 2017 
Berdasarkan data umur responden bahwa mayoritas umur responden produsen berada pada golongan umur antara 51-60 sebanyak 6 orang (40\%). Sedangkan untuk umur responden pedagang pengepul berada pada golongan umur 31-40 sebanyak 2 orang (100\%). Sedangkan untuk umur responden pedagang pengecer mayoritas berada pada golongan umur 51-60 sebanyak 4 orang $(57,14 \%)$. Konsumen akhir yang menjadi responden dalam penelitian ini mayoritas berumur 31-40 sebanyak 3 orang $(42,86 \%)$.

\section{Tingkat Pendidikan}

Tabel 2. Tingkat Pendidikan Responden

\begin{tabular}{|c|c|c|c|c|c|c|c|c|}
\hline \multirow{2}{*}{ Pendidikan } & \multicolumn{2}{|c|}{ Produsen } & \multicolumn{2}{|c|}{ Pengempul } & \multicolumn{2}{|c|}{ Pengecer } & \multicolumn{2}{|c|}{$\begin{array}{c}\text { Konsumen } \\
\text { Akhir }\end{array}$} \\
\hline & $\mathrm{Jml}$ & $\%$ & $\mathrm{Jml}$ & $\%$ & $\mathrm{Jml}$ & $\%$ & $\mathrm{jml}$ & $\%$ \\
\hline $\mathrm{SD}$ & 2 & 13,33 & - & - & 2 & 28,57 & - & - \\
\hline SMP & 4 & 26,67 & - & - & 1 & 14,29 & 1 & 14,29 \\
\hline SMA/SMK & 7 & 46,67 & 2 & $100 \%$ & 3 & 42,86 & 2 & 28,57 \\
\hline Sarjana & 2 & 13,33 & - & - & 1 & 14,29 & 4 & 57,14 \\
\hline Jumlah & 15 & 100 & 2 & 100 & 7 & 100 & 7 & 100 \\
\hline
\end{tabular}

Sumber :Analisis Data Primer, 2017

Berdasarkan Tabel 2, dapat diketahui bahwa responden produsen dan lembaga pemasaran mayoritas telah menempuh pendidikan sampai dengan tingkat Sekolah Menengah Atas (SMA). Hal ini sangat mempengaruhi seberapa besar pengetahuan mereka akan arti sebuah pemasaran. Mereka yang berpendidikan tinggi cenderung lebih berhati-hati dalam memasarkan produknya, sehingga resiko kerugian pun dapat terminimalisir. Responden konsumen akhir mayoritas telah menempuh pendidikan sarjana atau diploma. Hal ini mempengaruhi konsumen akhir saat membeli keripik tempe sesuai dengan kepuasan dan kebutuhannya.

Lama Menekuni Usaha

Tabel 3. Lama Menekuni Usaha

\begin{tabular}{cccccccc}
\hline \hline Lama Tekuni Usaha & & \multicolumn{2}{c}{ Produsen } & \multicolumn{3}{c}{ Pengepul } & \multicolumn{2}{c}{ Pengecer } \\
\cline { 2 - 8 } (Tahun) & jml & $\%$ & Jml & $\%$ & jml & $\%$ \\
\hline 1 Sampai 10 & 5 & 33,33 & - & - & 1 & 14,29 \\
11 Sampai 20 & 7 & 46,67 & 2 & 100 & 6 & 85,71 \\
21 Sampai 30 & 3 & 20 & - & - & - & - \\
$>30$ & - & - & - & - & - & - \\
\hline \hline Jumlah & 15 & 100 & 2 & 100 & 7 & 100 \\
\hline \hline
\end{tabular}

Sumber :Analisis Data Primer, 2017

Berdasarkan pengalaman responden, mayoritas sudah memiliki usaha yang cukup berkembang dan sudah lebih dari 10 tahun dalam menjalankan usahanya. 
Dalam penelitian ini, untuk responden produsen yang mayoritas sudah menekuni usaha selama $11-20$ tahun. Pedagang pengepul dan pengecer sudah menekuni usaha pemasaran keripik tempe selama 11 - 20 tahun. Dalam hal ini, usaha yang sudah ditekuni selama lebih dari 10 tahun mempermudah dalam menganalisa pemasaran keripik tempe tersebut sehingga keuntungan dari pemasaran keripik tempe dapat maksimal. Data lama menekuni usaha dapat dilihat pada Tabel 3.

\section{Asal Responden}

Tabel 4. Asal Responden

\begin{tabular}{ccccccccc}
\hline \hline \multirow{2}{*}{ Asal } & \multicolumn{2}{c}{ Produsen } & \multicolumn{3}{c}{ Pengumpul } & \multicolumn{2}{c}{ Pengecer } & \multicolumn{2}{c}{ Konsumen Akhir } \\
\cline { 2 - 9 } & $\mathrm{jml}$ & $\%$ & $\mathrm{Jml}$ & $\%$ & $\mathrm{jml}$ & $\%$ & $\mathrm{Jml}$ & $\%$ \\
\hline Asli Setempat & 15 & 100 & - & - & - & - & 2 & 28,57 \\
Pendatang & - & & 2 & 100 & 7 & 100 & 5 & 71,43 \\
\hline \hline Jumlah & 15 & 100 & 2 & 100 & 7 & 100 & 7 & 100 \\
\hline \hline
\end{tabular}

Sumber : Analisis Data Primer, 2017

Berdasarkan hasil penelitian menunjukkan bahwa responden produsen keripik tempe keseluruhan adalah penduduk asli setempat sebanyak 15 orang $(100 \%)$. Responden pedagang pengumpul berasal dari wilayah yang berbeda dengan produsen keripik tempe sebanyak 2 orang (100\%). Responden pedagang pengecer semuanya adalah penduduk pendatang sebanyak 7 orang $(100 \%)$ dan Konsumen akhir berasal dari desa lerep sebanyak 2 orang $(28,57 \%)$ dan dari luar daerah lerep sebanyak 5 orang $(71,43 \%)$. Berdasarkan data tersebut menunjukkan bahwa lembaga pemasaran dan konsumen akhir mayoritas berasal dari luar Desa.

\section{Jumlah Produksi}

Produsen memproduksi keripik tempe sebanyak 3 kali dalam satu periode atau satu minggu. Setiap 1 kali produksi produsen mampu memproduksi sebanyak $13 \mathrm{~kg}$ keripik tempe. Sehingga dalam satu periode/minggu, produsen mampu memproduksi sebanyak $39 \mathrm{Kg}$. Setiap periode, keripik tempe diambil oleh pengepul dan pengecer maupun dijual langsung kepada konsumen akhir. Pengepul mengambil keripik tempe sebanyak $19 \mathrm{Kg}$ setiap periode. Pengecer mengambil keripik tempe dari produsen sebanyak $14 \mathrm{Kg}$ setiap periode. Sedangkan $6 \mathrm{Kg}$ keripik tempe yang tersisa langsung dijual kepada konsumen akhir setiap periodenya. Jumlah produksi keripik tempe dalam satu periode dapat dilihat pada Tabel 5 berikut.

Tabel 5. Jumlah Produksi Keripik Tempe dalam 1 Periode/Minggu

\begin{tabular}{|c|c|c|c|c|c|}
\hline \multirow[b]{2}{*}{ No } & \multirow[b]{2}{*}{ Lembaga } & \multicolumn{2}{|c|}{ Jumlah Produksi $(\mathrm{kg})$} & \multirow{2}{*}{$\begin{array}{l}\text { Jumlah Barang } \\
\text { Yang Diambil } \\
\text { (Kg/ Minggu) }\end{array}$} & \multirow[b]{2}{*}{$\begin{array}{c}\text { Prosentase } \\
(\%)\end{array}$} \\
\hline & & $\begin{array}{l}\text { Kuantitas } \\
(\mathrm{Kg})\end{array}$ & $\begin{array}{l}\text { Produksi } \\
\text { (Kali) }\end{array}$ & & \\
\hline 1 & Produsen & 13 & 3 & & \\
\hline 2 & Pengepul & & & 19 & 48,72 \\
\hline 3 & Pengecer & & & 14 & 35,90 \\
\hline 4 & Konsumen Akhir & & & 6 & 15,38 \\
\hline & Total & & & 39 & 100 \\
\hline
\end{tabular}


Sumber: Analisis Data Primer, 2017

\section{Lembaga Pemasaran Keripik Tempe}

Lembaga pemasaran keripik tempe di Desa Lerep Kecamatan Ungaran Barat Kabupaten Semarang terdiri dari produsen keripik tempe, pedagang pengepul atau pengumpul, dan pedagang pengecer. Produsen adalah salah satu lembaga pemasaran keripik tempe yang ada di Desa Lerep Kecamatan Ungaran Barat Kabupaten Semarang karena produsen keripik tempe selain memproduksi keripik tempe juga menjual produknya langsung ke konsumen akhir dengan kata lain, produsen adalah lembaga pemasaran yang aktif melakukan pemasaran keripik tempe.

Pedagang pengepul keripik tempe di Desa Lerep Kecamatan Ungaran Barat Kabupaten Semarang adalah lembaga pemasaran yang membeli keripik tempe langsung kepada produsen keripik tempe. Pedagang pengepul menerima keripik tempe dari 4 produsen dengan jumlah sebesar 48,72\% dalam seminggu untuk memenuhi permintaan konsumen.

Pedagang yang mengecerkan keripik tempe adalah pedagang yang menjual keripik tempe kepada konsumen secara langsung. Pengecer mendapatkan keripik tempe ada yang mendapatkannya dari produsen langsung dan ada yang melalui perantara (pedagang pengumpul). Pedagang pengecer biasanya hanya mengambil dan menjual keripik tempe sebanyak 35,90\% dalam seminggu.

\section{Saluran Pemasaran Keripik Tempe}

Saluran pemasaran keripik tempe yang ada di Desa Lerep Kecamatan Ungaran Barat Kabupaten Semarang terdiri dari tiga saluran yaitu :

a. Saluran pemasaran 1: Produsen-Konsumen Akhir

Pada saluran pemasaran keripik tempe ini, produsen langsung menjual hasil olahannya (keripik tempe) kepada konsumen. Pada saluran ini, konsumen membeli dengan jumlah yang relatif sedikit karena pembelian yang dilakukan konsumen langsung ke produsen hanya untuk memenuhi kebutuhan dirinya sendiri atau hanya untuk membawa bingkisan khas Kabupaten Semarang kepada saudara di kampung halaman (oleh - oleh).

Sistem pembayaran yang terjadi pada saluran ini adalah sistem pembayaran tunai. Pada saluran ini, produsen memilih untuk menjual langsung keripik tempe ke konsumen karena keripik tempe yang mudah rusak, tengik yang harus langsung terjual. Pada saluran ini, kelemahannya adalah keripik tempe yang di produksi tidak langsung habis terjual karena konsumen membeli keripik tempe dengan jumlah yang sedikit dan tidak terus menerus (kondisional).

b. Saluran pemasaran 2: Produsen-Pengecer-Konsumen akhir

Pada saluran kedua, produsen keripik tempe menjual hasil produksinya kepada pedagang pengecer. Selanjutnya pedagang pengecer menjual kembali kepada konsumen akhir. Saluran Pemasaran ke 2 ini melibatkan lembaga pemasaran yaitu pedagang pengecer. Lembaga pemasaran yang terlibat dalam saluran ini bertujuan 
memberikan kemudahan produsen dalam memasarkan keripik tempe ke konsumen.

Pengecer yang membeli keripik tempe langsung dari produsen mendapatkan harga sebesar Rp. 39.000,-/ Kg. Sistem pembayaran yang dilakukan antara produsen keripik tempe dengan pengecer adalah pembayaran tunai. Pembayaran tunai ini dilakukan karena lebih mengurangi resiko pada saat transaksi. Pengecer membeli keripik tempe 2 kali dalam 1 minggu sebanyak $9 \mathrm{Kg}$ dan berlangsung terus menerus (kontinue).

Pengecer menjual keripik tempe kepada konsumen dengan harga jual yang ditetapkan oleh pengecer tersebut. Keuntungan produsen pada saluran ini adalah produsen tidak menyimpan keripik tempe terlalu lama setelah produksi dan pada saat terjadi kerusakan yang menanggung semuanya adalah pengecer.

\section{c. Saluran pemasaran 3: Produsen-Pengumpul-Pengecer-Konsumen akhir}

Pada saluran ketiga, produsen keripik tempe menjual hasil produksinya kepada pedagang pengumpul. Selanjutnya pedagang pengumpul menjual kembali kepada pedagang pengecer dan dilanjutkan ke konsumen akhir. Lembaga pemasaran yang terlibat dalam pemasaran keripik tempe ini adalah pedagang pengumpul/ pengepul dan pedagang pengecer.

Pedagang pengepul membeli keripik tempe 2 kali dalam 1 minggu dengan jumlah rata - rata sebanyak $19 \mathrm{Kg}$ dari produsen. Setelah membeli keripik tempe pengepul/ pengumpul menjual kembali keripik tempe kepada pedagang pengecer setelah itu pengecer menjual produknya kepada konsumen. Sistem pembayaran yang diterapkan dalam saluran ini adalah sistem pembayaran secara tunai. Kelebihan dari saluran ini adalah produsen tidak sulit untuk menjual produknya dikarenakan pengepul sudah membeli keripik tempe dalam jumlah yang banyak dan terus menerus.

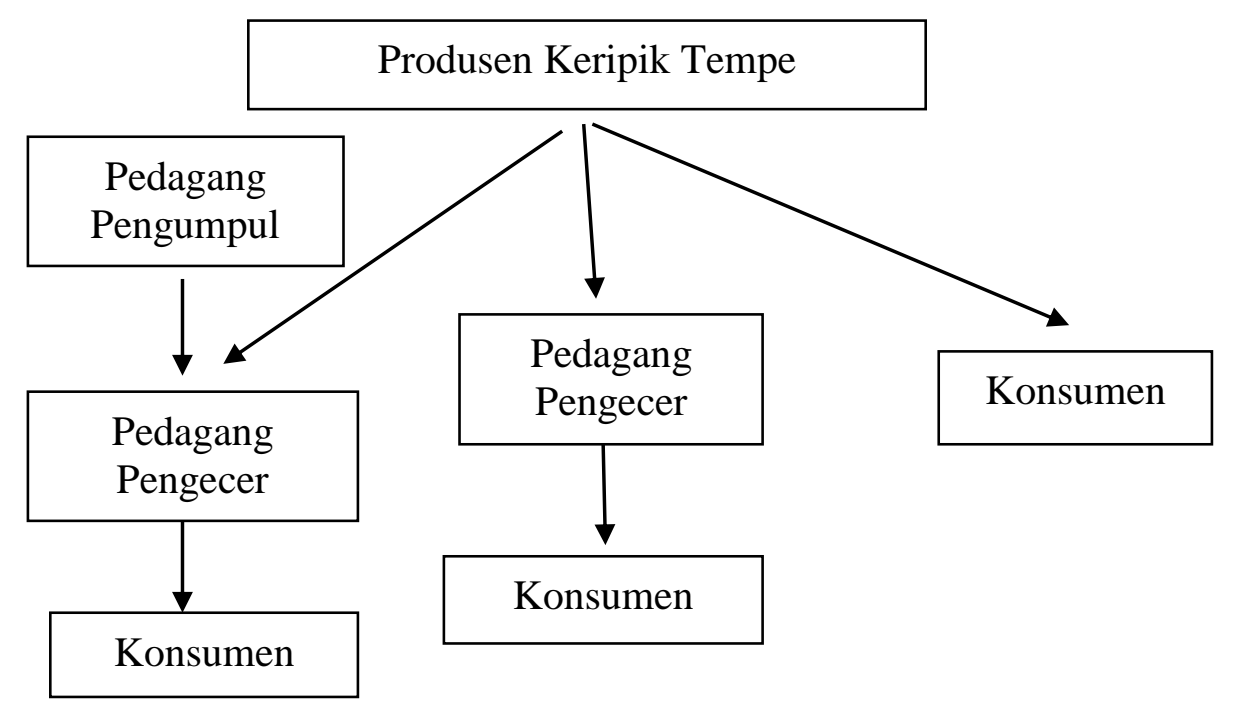

Gambar 1. Saluran Pemasaran Keripik Tempe di Desa Lerep Kecamatan Ungaran Barat Kabupaten Semarang. 


\section{Analisis Biaya Dan Margin Pemasaran Keripik Tempe a. Biaya Dan Margin pada Saluran Pemasaran 1}

Tabel 6. Biaya dan Margin Pemasaran Keripik Tempe Saluran Pemasaran I.

\begin{tabular}{lrr}
\hline \hline Lembaga Pemasaran & Margin $(\mathrm{Rp} / \mathrm{Kg})$ & Pangsa (\%) \\
\hline Produsen & & \\
Harga Dasar & 39.000 & 89,66 \\
Biaya Plastik & 120 & 0,28 \\
Harga jual & 43.500 & 100 \\
\hline Konsumen & & \\
Harga beli & 43.500 & 100 \\
\hline Margin Pemasaran & 4.380 & 10,07 \\
\hline
\end{tabular}

Sumber : Analisis Data Primer, 2017

Pada saluran pemasaran pertama, produsen keripik tempe menjual langsung ke konsumen dengan harga Rp. 43.500,- per kg. Saluran I memiliki margin sebesar Rp. 4.380,- atau (10,07\%). Produsen disini sekaligus menjadi lembaga pemasaran keripik tempe yang mempunyai tambahan keuntungan tinggi. Tambahan keuntungan/margin yang diterima produsen tinggi akan tetapi resiko pada saat pemasaran lebih tinggi akibat keripik tempe adalah produk yang mudah rusak, mudah bau tengik dan tidak tahan lama sedangkan konsumen membeli secara langsung hanya pada saat tertentu dan untuk kegunaan pribadi saja. Jadi produsen membutuhkan waktu lama dalam pemasaran keripik tempe pada saluran ini. Selain karakteristik produk yang mudah rusak menurut Carani (2006), tidak semua pengrajin dapat menggunakan saluran ini karena bagi mereka yang mengolah kedelai lebih dari $100 \mathrm{~kg}$ akan mengalami kesulitan untuk memasarkan sendiri hasil produksinya sehingga mereka membutuhkan lembaga pemasaran untuk memasarkan produk mereka.

\section{b. Biaya Dan Margin pada Saluran Pemasaran 2}

Jumlah lembaga pemasaran atau pedagang perantara yang terlibat dalam kegiatan pemasaran pada saluran pemasaran dua adalah dua lembaga yang terdiri dari produsen, pedagang pengecer, dan konsumen akhir. Pada saluran pemasaran ini, produsen keripik tempe menjual keripik tempe melalui pedagang pengecer dan kemudian ke konsumen akhir.

Pada Tabel 7 memperlihatkan saluran pemasaran kedua memiliki total margin sebesar Rp. 4.500,- atau (10,34\%). Pada saluran ini, biaya yang timbul sebesar Rp.513. Total keuntungan yang didapat pada saluran II sebesar Rp. 3.987,-. Pada saluran ini produsen tidak memiliki resiko yang terlalu besar karena produsen tidak menyimpan keripik tempe terlalu lama karena pengecer membeli keripik tempe dari produsen dalam jumlah yang cukup banyak. 
Tabel 7. Biaya Dan Margin Pemasaran Keripik Tempe Saluran Pemasaran II

\begin{tabular}{lrr}
\hline \hline Lembaga Pemasaran & Margin $(\mathrm{Rp} / \mathrm{Kg})$ & Pangsa $(\%)$ \\
\hline Produsen & 39.000 & 89,66 \\
Harga jual & & \\
\hline Pedagang Pengecer & 39.000 & 89,66 \\
Harga beli & 43.500 & 100 \\
Harga jual & 513 & 1,18 \\
Total biaya pemasaran & 105 & 0,24 \\
$\quad-$ Biaya pengemasan & 247 & 0,57 \\
$\quad-$ Biaya transportasi & 161 & 0,37 \\
$\quad-$ Biaya Parkir & 4.500 & 10,34 \\
Margin Pemasaran & 3.987 & 9,17 \\
Margin Keuntungan & & \\
\hline Konsumen & 43.500 & 100 \\
Harga beli & 513 & 1,18 \\
\hline Total Biaya Pemasaran & 4.500 & 10,34 \\
Total Margin Pemasaran & 3.987 & 9,17 \\
Total Margin keuntungan & & \\
\hline \hline
\end{tabular}

Sumber: Analisis Data Primer, 2017

\section{c. Biaya Dan Margin pada Saluran Pemasaran 3}

Saluran pemasaran ini, produsen menjual keripik tempe melalui pedagang pengumpul/pengecer, pedagang pengecer dan kemudian ke konsumen akhir. Lembaga pemasaran yang terlibat dalam saluran ini adalah 3 lembaga yang terdiri dari produsen, pengepul, dan pengecer.

Pada Tabel 8 memperlihatkan saluran ini memiliki total margin sebesar Rp. 4.500,- atau (10,34\%). Pada saluran ini, total biaya yang timbul sebesar Rp.815. Total keuntungan yang didapat pada saluran III sebesar Rp. 3.685,-. Pada saluran ini produsen tidak memiliki resiko yang terlalu besar karena produsen tidak menyimpan keripik tempe terlalu lama karena Pengecer dan pengepul membeli keripik tempe dari produsen dalam jumlah yang cukup banyak. 
Tabel 8. Biaya Dan Margin Pemasaran Keripik Tempe Saluran Pemasaran III

\begin{tabular}{|c|c|c|}
\hline Lembaga Pemasaran & $\operatorname{Margin}(\mathrm{Rp} / \mathrm{Kg})$ & Pangsa (\%) \\
\hline \multicolumn{3}{|l|}{ Produsen } \\
\hline Harga jual & 39.000 & 89,66 \\
\hline \multicolumn{3}{|l|}{ Pedagang Pengumpul } \\
\hline Harga beli & 39.000 & 89,66 \\
\hline Harga jual & 41.000 & 94,25 \\
\hline Total Biaya Pemasaran & 302 & 0,69 \\
\hline - Biaya pengemasan & 118 & 0,27 \\
\hline - Biaya transportasi & 184 & 0,42 \\
\hline Margin Pemasaran & 2.000 & 4,60 \\
\hline Margin Keuntungan & 1.698 & 3,90 \\
\hline \multicolumn{3}{|l|}{ Pedagang Pengecer } \\
\hline Harga beli & 41.000 & 94,25 \\
\hline Harga jual & 43.500 & 100 \\
\hline Total Biaya Pemasaran & 513 & 1,18 \\
\hline - Biaya transportasi & 105 & 0,24 \\
\hline - Biaya pengemasan & 247 & 0,57 \\
\hline - Biaya Parkir & 161 & 0,37 \\
\hline Margin Pemasaran & 2.500 & 5,74 \\
\hline Margin Keuntungan & 1.987 & 4,58 \\
\hline \multicolumn{3}{|l|}{ Konsumen } \\
\hline Harga beli & 43.500 & 100 \\
\hline Total Biaya Pemasaran & 815 & 1,87 \\
\hline Total Margin Pemasaran & 4.500 & 10,34 \\
\hline Total Margin keuntungan & 3.685 & 8,47 \\
\hline
\end{tabular}

Sumber : Analisis Data Primer, 2017

\section{Analisis Efisiensi Dan Keuntungan Pemasaran Keripik Tempe}

Tabel 9. Analisis Keuntungan Tiap Saluran Pemasaran Pada Pemasaran Keripik Tempe Di Desa Lerep Kecamatan Ungaran Barat Kabupaten Semarang.

\begin{tabular}{ccccccr}
\hline \hline No. & $\begin{array}{c}\text { Lembaga } \\
\text { Pemasaran }\end{array}$ & $\begin{array}{c}\text { Harga } \\
\text { Dasar } \\
(\mathrm{Rp} / \mathrm{Kg})\end{array}$ & $\begin{array}{c}\text { Harga } \\
\text { Beli } \\
(\mathrm{Rp} / \mathrm{Kg})\end{array}$ & $\begin{array}{c}\text { Harga } \\
\text { Jual } \\
(\mathrm{Rp} / \mathrm{Kg})\end{array}$ & $\begin{array}{c}\text { Biaya } \\
\text { Pemasaran } \\
(\mathrm{Rp} / \mathrm{Kg})\end{array}$ & $\begin{array}{c}\text { Keuntungan } \\
(\mathrm{Rp} / \mathrm{Kg})\end{array}$ \\
\hline 1. & Saluran 1 & 39.000 & - & 43.500 & 120 & 4.380 \\
2. & Saluran 2 & - & 39.000 & 43.500 & 513 & 3.987 \\
3 & Saluran 3 & - & 41.000 & 43.500 & 815 & 3.685 \\
\hline \hline
\end{tabular}

Sumber : Analisis Data Primer, 2017

Berdasarkan Tabel 9 dapat dilihat bahwa saluran 1 adalah saluran yang mempunyai keuntungan/ tambahan keuntungan lebih besar dibandingkan saluran 
lainnya. Ini disebabkan karena produsen langsung menjual keripik tempe langsung kepada konsumen akhir. Meskipun saluran I memberikan keuntungan yang terbesar, tidak semua produsen dapat menggunakan saluran ini sesuai dengan yang dikemukakan oleh Carani (2006) Meskipun saluran I memberikan bagian harga yang diterima produsen paling besar/ keuntungan yang terbesar, tidak semua produsen dapat menggunakan saluran ini karena bagi mereka yang mengolah kedelai lebih dari $100 \mathrm{~kg}$ akan mengalami kesulitan untuk memasarkan sendiri hasil produksinya sehingga mereka membutuhkan lembaga pemasaran untuk memasarkan produknya.

Tabel 10. Analisis Efisiensi Pemasaran Keripik Tempe di Desa Lerep Kecamatan Ungaran Barat Kabupaten Semarang

\begin{tabular}{clrrr}
\hline \hline No. & Saluran Pemasaran & Biaya $(\mathrm{Rp} / \mathrm{Kg})$ & $\begin{array}{c}\text { Nilai Produk } \\
(\mathrm{Rp} / \mathrm{Kg})\end{array}$ & $\begin{array}{c}\text { Nilai Efisiensi } \\
(\%)\end{array}$ \\
\hline 1. & Saluran I & 120 & 43.500 & 0,26 \\
2. & Saluran II & 513 & 43.500 & 1,18 \\
3. & Saluran III & 815 & 43.500 & 1,87 \\
\hline \hline
\end{tabular}

Sumber : Analisis Data Primer, 2017

Berdasarkan Tabel 10, efisiensi pemasaran terjadi pada semua saluran, karena semua saluran tidak lebih dari 5\%. Dilihat dari presentasenya, saluran ke II memiliki nilai efisiensi paling tinggi sebesar $1,18 \%$. Dilihat dari efisiensi pemasaran produk, saluran II adalah saluran yang efisien untuk memasarkan keripik tempe karena keripik tempe adalah produk yang mudah rusak dan tidak tahan lama, jadi saluran II adalah saluran yang tidak banyak melalui lembaga pemasaran dan tidak membutuhkan waktu lama produk sampai ke tangan konsumen. Hal ini sesuai dengan hasil penelitian Rahim (2016), bahwa terdapat 3 saluran pemasaran keripik tempe di Desa Pasir Agung Kecamatan Bangun Purba dan ketiga saluran tersebut sudah efisien.

\section{KESIMPULAN}

Kesimpulan yang dapat diambil dari penelitian ini diantaranya terdapat tiga saluran pemasaran keripik tempe di Desa Lerep Kecamatan Ungaran Barat Kabupaten Semarang. Saluran I terdiri dari : Produsen - Konsumen Akhir, Saluran II terdiri dari : Produsen - Pedagang Pengecer - Konsumen Akhir dan Konsumen III terdiri dari : Produsen - Pedagang Pengepul - Pedagang Pengecer Konsumen Akhir. Total nilai margin pemasaran pada saluran I sebesar Rp. 4.380, saluran II sebesar Rp. 4.500,- dan saluran III sebesar Rp. 4.500. Biaya yang timbul pada saluran I sebesar Rp. 120, pada saluran II sebesar Rp. 513 dan pada saluran III sebesar Rp. 815. Nilai efisiensi tiap saluran pemasarannya tidak lebih dari 5\%. Selain itu untuk biaya yang dikeluarkan tiap saluran pemasaran lebih kecil dibandingkan dengan keuntungan atau pendapatan yang diterima oleh tiap lembaga tersebut. Nilai efisiensi pemasaran tiap saluran adalah saluran I sebesar $0,26 \%$, saluran II sebesar $1,18 \%$, dan saluran III sebesar $1,87 \%$. 


\section{SARAN}

Berdasarkan hasil penelitian yang dilakukan, maka hal yang dapat disarankan yaitu produsen keripik tempe di Desa Lerep Kecamatan Ungaran Barat Kabupaten Semarang lebih efisien menggunakan saluran II dalam pemasaran keripik tempe sehari - hari dikarenakan melihat karakteristik keripik tempe yang mudah rusak dan tengik sehingga resiko produsen lebih kecil dibandingkan dengan saluran lainnya. Kemasan keripik tempe diberi nama dagang atau merk dari produsen, selain itu kemasan keripik tempe di beri tanggal kadaluwarsa agar konsumen lebih dimudahkan dan keripik tempe dikemas dalam kemasan yang lebih menarik agar konsumen lebih tertarik dengan keripik tempe dari Desa Lerep Kecamatan Ungaran barat Kabupaten Semarang. Produsen Keripik Tempe di Desa Lerep Kecamatan Ungaran Barat Kabupaten Semarang mendaftarkan produknya ke dinas terkait agar mendapatkan nomor PIRT (Sertifikat Pangan) dan menjadi kelompok UMKM di Kabupaten Semarang.

\section{DAFTAR PUSTAKA}

Carani, Intan. (2006). Analisis Kinerja Saluran Pemasaran Indusrti Kecil Tahu Kasus Pengrajin Tahu Kelurahan Pasir Jaya, Kecamatan Bogor Barat. Skripsi S1. Institut Pertanian Bogor. Bogor.

Firdaus, M. (2009). Manajemen Agribisnis. Bumi Aksara. Jakarta.

Januwiata, I.K., dkk. (2013). Analisis Saluran Pemasaran Usahatani Jeruk Di Desa Kerta Kecamatan Payangan Kabupaten Gianyar Bali. Jurnal Penelitian. Vol:4, No: 1. Universitas Pendidikan Ganesha. Bali

Nazir, Moh. (2005). Metode Penelitian. Cetakan keempat. Ghalia Indonesia. Jakarta.

Rahim, Abdul. (2016). Identifikasi Distribusi Saluran Pemasaran Keripik Tempe Di Desa Pasir Agung Kecamatan Bangun Purba Kabupaten Rokan Hulu Studi Kasus Usaha Keripik Tempe Ibu Pur. Naskah Publikasi. Universitas Pasir Pengaraian. Rokan Hulu. Diakses pada tanggal 10 Oktober 2016.Sarwono, B. (2007). Membuat Tempe dan Oncom. Penebar Swadaya. Jakarta.

Sarwono, B. (2007). Membuat Tempe dan Oncom. Penebar Swadaya. Jakarta.

Sudiyono. (2002). Pemasaran Pertanian. UMM Press. Malang.

Soekartawi. (2002). Prinsip Dasar Manajemen Pemasaran Hasil - Hasil Pertanian. Edisi Revisi. PT Raja Grafindo Indonesia. Jakarta 